\title{
Identification of resistance sources against bacteria blight of cotton caused by Xam race no. 18
}

\author{
S.P. PATOLE*, R.S. SALUNKHE AND A.D. PHAPALE
}

Department of Plant Pathology and Agricultural Microbiology, Mahatma Phule Krishi Vidyapeeth, Rahuri, AHMEDNAGAR (M.S.) INDIA

\section{ARITCLE INFO}

Received : 02.08 .2016

Revised : 30.08 .2016

Accepted : 14.09 .2016

KEY WORDS :

Gynotypes, Cotton, Bacterial blight, Race no. 18

*Corresponding author:

Email :

santoshpatole57@rediffmail.com.com

\section{ABSTRACT}

Cotton, "king of fibres" enjoys a pre-eminent status among all cash crops in the country, being the principal raw material for a flourishing textile industry. Among the various diseases occurring on cotton, the foliar disease bacterial blight caused by Xanthomonas axonopodis pv. malvacearum is gaining more importance in recent years because of their increasing incidence. These have been known to occur on all the various cultivated and wild species of cotton in Maharashtra, since many years, in an epiphytotic form on commercially grown varieties, which leads to severe defoliation and substantial yield lossess. Among the 221 cultivated genotypes screened for resistance against bacterial leaf blight disease under field conditions, 80 genotypes showed immune reaction. Further, 69 genotypes were resistant, 13 genotypes were moderately resistant, The 19 entries showed the moderately susceptible reaction and 40 entries showed the susceptible reaction to the bacterial blight disease.

How to view point the article : Patole, S.P., Salunkhe, R.S. and Phapale, A.D. (2016). Identification of resistance sources against bacteria blight of cotton caused by Xam race no. 18. Internat. J. Plant Protec., 9(2) : 527-531, DOI : 10.15740/HAS/IJPP/9.2/527-531. 